\title{
Utilization of statins, an HMG-CoA reductase inhibitors, in Ambon District Hospital, Maluku: a retrospective study
}

\author{
Abraham Simatupang ${ }^{*}$, Yusuf Huningkor ${ }^{2}$, Westi C Gasperz ${ }^{2}$, Maria Nindatu², Farah \\ Noya $^{2}$, Marliyati Sanaky², Inggrid Hutagalung ${ }^{2}$, Denny Yolanda ${ }^{2}$, Natalie Kailola² \\ ${ }^{1}$ Department of Pharmacology \& Therapy, Faculty of Medicine, Universitas Kristen \\ Indonesia, Jakarta, Indonesia, ${ }^{2}$ Department of Internal Medicine - Faculty of Medicine - \\ Universitas Pattimura, Dr. Haulussy District General Hospital, Ambon, Indonesia
}

DOI: http://dx.doi.org/10.19106/JMedSci005002201810

\begin{abstract}
Non-infectious diseases, including hypercholesterolemia, are now ranked top 10 in Indonesia. Statins are inhibitors of HMG-CoA reductase, an enzyme for biosynthesis of cholesterol in the liver. Statins have been proven to reduce the risk of death due to $\mathrm{CHD}$ and mortality from various reasons. The objective of the study is to know the utilization of statins in peripheral area of Indonesia. This retrospective study on utilization of statins prescribed for hypercholesterolemia was taken from medical record year of 2014-2015 of a District Hospital - Dr. Haulussy, Ambon, and Maluku. We collected demographic data, pre- and treated concentrations of total cholesterol (TC), low-density lipoprotein cholesterol (LDL-C), high-density lipoprotein cholesterol (HDL-C), and triglyceride (TG), types and dosages of statins or other lipid-lowering medications given. Student t-test using was performed to check statistical differences for all cholesterol and TG differences prior to therapy versus during treatment. Eighty three respondents consisted of 26 men $(31.3 \%)$ and 57 women (68.7\%) with mean age $60 \pm 11$ years old. The pre-treatment/ post-treatment values $(\mathrm{mg} / \mathrm{dL})$ of TC: $245.22 \pm 51.40 / 224.97 \pm 98.79(p=0.004)$; LDL-C: $166.07 \pm 45.36 / 146.00 \pm 41.07$; HDL-C: $54.52 \pm 37.95 / 43.00 \pm 0.00$; and TG: $177.36 \pm 103.25 / 121.00 \pm 52.87$, respectively. Seventy-nine patients $(95.2 \%)$ were treated with statins. The dosage given were $10 \mathrm{mg}(\mathrm{n}=19,22.9 \%), 20 \mathrm{mg}(\mathrm{n}=$ $63,75.9 \%)$, and $40 \mathrm{mg}(\mathrm{n}=1,1.2 \%)$. Twenty-eight patients $(33.7 \%)$ had no posttreatment data of cholesterol, and 31 out of 55 patients (56\%) were responders. All cholesterol levels were decreased, but responder rate was only $56 \%$. Therefore, dosage adjustment and prerequisite cholesterol level during and post-treatment measurement should be made regularly.
\end{abstract}

\section{ABSTRAK}

Penyakit non-infeksi, termasuk hiperkolesterolemia, sekarang menduduki peringkat 10 teratas di Indonesia. Statin adalah inhibitor HMG-CoA reduktase, yaitu enzim untuk biosintesis kolesterol di hati. Statin telah terbukti mengurangi risiko kematian akibat PJK dan kematian akibat berbagai alasan. Tujuan dari penelitian ini untuk mengetahui pemanfaatan statin di daerah periferal Indonesia. Penelitian retrospektif tentang pemanfaatan statin yang diresepkan untuk hiperkolesterolemia diambil dari rekam medis tahun 2014-2015 dari Rumah Sakit Distrik - Dr. Haulussy, Ambon, dan Maluku. Kami mengumpulkan data demografi, konsentrasi pra-perlakuan dan kolesterol Total (TC),

\footnotetext{
* corresponding author : abraham.simatupang@uki.ac.id
} 
kolesterol low-density lipoprotein (LDL-C), kolesterol HDT, dan Trigliserida (TG), jenis dan dosis statin atau obat penurun lipid lainnya yang diberikan. Uji t dilakukan untuk memeriksa perbedaan statistik untuk semua perbedaan kolesterol dan TG sebelum terapi dibandingkan selama pengobatan. Delapan puluh tiga responden terdiri dari 26 pria $(31,3 \%)$ dan 57 wanita $(68,7 \%)$ dengan usia rata-rata $60 \pm 11$ y.o. Nilai praperawatan/pasca perawatan $(\mathrm{mg} / \mathrm{dL})$ dari TC: $245,22 \pm 51,40 / 224,97 \pm 98,79(\mathrm{p}$ $=0,004)$; LDL-C: $166.07 \pm 45.36 / 146.00 \pm 41.07$; HDL-C: $54,52 \pm 37,95 / 43,00$ \pm 0,00; dan TG: $177,36 \pm 103,25 / 121,00 \pm 52,87$. Tujuh puluh sembilan pasien $(95,2 \%)$ diobati dengan statin. Dosis yang diberikan adalah $10 \mathrm{mg}(\mathrm{n}=19,22,9 \%)$, $20 \mathrm{mg}(\mathrm{n}=63 ; 75,9 \%)$, dan $40 \mathrm{mg}(\mathrm{n}=1 ; 1,2 \%)$. Dua puluh delapan pasien $(33,7 \%)$ tidak memiliki data pasca perawatan kolesterol, dan 31 dari 55 pasien (56\%) adalah responden. Semua kadar kolesterol menurun, tetapi tingkat responden hanya $56 \%$. Oleh karena itu, penyesuaian dosis dan pengukuran tingkat kolesterol prasyarat selama dan pasca perawatan harus dilakukan secara teratur.

Keywords: Statins, drug utilization, hypercholesterolemia, HMG-CoA reductase inhibitor

\section{INTRODUCTION}

Coronary heart disease (CHD) is substantially replacing communicable diseases in many low- and middle-income countries, including Indonesia. And dyslipidemia is one of the major risk-factors of CHD. According to the latest data metabolic disease is now ranked. The first attempt to lower the risk is by changing their lifestyles, which include reducing the body weight, low animal fat and high fibre diet, taking exercise and smoking cessation. However, these efforts could only reduce the cholesterol level up to $15 \%{ }^{1}$

Statins are group of lipid-lowering drugs, which have been proven by many clinical trials not only in lowering the cholesterol level but also cardiovascular diseases in primary and secondary prevention studies. ${ }^{2-6}$ From these short and medium-term clinical trial data and long-term clinical studies, the National Cholesterol Education Program (NCEP) Adult Treatment Panel III (ATP III) established targets for LDL-C that depend on the individual risk of the patient, with the lowest LDL-C targets $(<100 \mathrm{mg} / \mathrm{dL})$ recommended for patients with $\mathrm{CHD}$ or other forms of vascular disease. ${ }^{7,8}$ However, recently American College of Cardiology/
American Heart Association (ACC/AHA) in 2013 made another approach which is focused not on lowering LDL-C level per se, but make statins the linchpin of their recommendation. ${ }^{9}$ This notion was made due to lack of clinical evidences to support titration of drug therapy to specific LDL-C and/or non-HDL-C goals. On contrary, the intensity of statin therapy did show evidences on reducing the CHD. ${ }^{10}$ Evidence suggests that in actual practice it is often the goal of decreasing cholesterol levels is not achieved especially in developing countries. Previous studies showed that there is a huge gap on the effectiveness of statin used in clinical practice in comparison with clinical trials. ${ }^{11-13}$

The aim of the study was to investigate the utilization of statin in peripheral area of Indonesia. The data was gathered from a district hospital in Maluku province, Indonesia.

\section{MATERIALS AND MethodS}

\section{Subjects}

A retrospective study on utilization of statins prescribed for hypercholesterolemia was conducted by collecting data from medical record year of 2014-2015 from District 
Hospital - Dr. Haulussy, Ambon, Maluku. The inclusion criteria were 1) all patients diagnosed with primary hypercholesterolemia with a value of $\mathrm{TC} \geq 240 \mathrm{mg} / \mathrm{dL}$ or $\mathrm{LDL}$ cholesterol: $\geq 160 \mathrm{mg} / \mathrm{dL}$ with or without other complications (e.g. T2DM); 2) all of the above patients who were given statin-lowering cholesterol-lowering drugs (HMG-CoA reductase inhibitor); 3 ) statins that are used as main drugs or supplemental drugs with other cholesterol-lowering. The exclusion criteria were 1) all subjects diagnosed not with primary hypercholesterolemia; 2) subjects who were diagnosed with primary hypercholesterolemia but did not receive any statins; 3) subjects who have had not measurement of cholesterol concentration prior to treatment with statin.

\section{Protocol of study}

Patients' medical records were reviewed to select patients who fulfil the inclusion and exclusion criteria. The data collection form was prepared to collect patients' characteristics (gender and age), diagnosis, relevant laboratory value of pre- and during treatment i.e. total cholesterol (TC), lowdensity lipoprotein cholesterol (LDL-C), highdensity lipoprotein cholesterol (HDL-C), and triglyceride (TG), concomitant of diseases i.e. T2DM, hypertension, chronic kidney diseases), and prescribed medications (types of statins or other lipid-lowering medications given, and dosages of statins).

\section{Statistical analysis}

Data of cholesterol profile and TG were presented as mean \pm standard deviation (SD). Student t-test was performed using SPSS ver. 22 to determine statistical differences for all cholesterol and TG differences pre treatment and at the time the data collected.

\section{RESULTS}

We gathered data from eighty three respondents consisted of 26 men $(31.3 \%)$ and 57 women $(68.7 \%)$ with mean of age $60 \pm 11$ years old. Seventy nine subjects $(95.2 \%)$ were treated with simvastatin, 3 subjects (3.61\%) with atorvastatin and 1 patient $(1.20 \%)$ with pravastatin, respectfully. The dosage given were $10 \mathrm{mg}(\mathrm{n}=19,22.9 \%), 20 \mathrm{mg}(\mathrm{n}=63$, $75.9 \%)$, and $40 \mathrm{mg}(\mathrm{n}=1,1.2 \%)$. Twenty-eight subjects $(33.7 \%)$ had no post-treatment data of cholesterol. None of them reached the targeted LDL-C concentration of $<100 \mathrm{mg} / \mathrm{dL}$.

It is clearly shown from TABLE 1 that the only parameter for diagnosis and for follow-up is total cholesterol and only few were measured their non-HDL cholesterol and LDL-C. Moreover, very few subjects who were followedup to measure the effect of the treatment.

TABLE 1. Cholesterol profiles (mean \pm SD) of respondents pre treatment and at the time of data collected

\begin{tabular}{|c|c|c|c|c|}
\hline $\begin{array}{c}\text { Cholesterol } \\
\text { (mg/dL) }\end{array}$ & $\begin{array}{l}\text { Pretreatment } \\
\text { (n) }\end{array}$ & $\begin{array}{l}\text { Treatment } \\
\text { (n) }\end{array}$ & CI & p \\
\hline $\mathrm{TC}$ & $\begin{array}{c}245.22 \pm 51.4 \\
(83)\end{array}$ & $\begin{array}{c}224.97 \pm 98.8 \\
(39)\end{array}$ & $13.4-64.2$ & 0.004 \\
\hline LDL-C & $\begin{array}{c}166.07 \pm 45.4 \\
(27)\end{array}$ & $\begin{array}{c}146.00 \pm 41.1 \\
\text { (3) }\end{array}$ & $-111.4-174$ & 0.445 \\
\hline HDL-C & $\begin{array}{c}54.52 \pm 37.95 \\
(25)\end{array}$ & $\begin{array}{c}43.00 \pm 0.00 \\
\text { (2) }\end{array}$ & $-97.35-131$ & 0.310 \\
\hline TG & $\begin{array}{c}177.36 \pm 103.2 \\
(28)\end{array}$ & $\begin{array}{c}121.00 \pm 52.87 \\
(5)\end{array}$ & $-97.37-137$ & 0.661 \\
\hline
\end{tabular}


TABLE 2 shows that only $14.45 \%$ of subjects are diagnosed with dyslipidaemia and the rest of them having comorbidities such as hypertension, type 2 diabetes mellitus (T2DM), and chronic kidney diseases (CKD).

TABLE 2. Type of diagnosis and number of cases

\begin{tabular}{lcc}
\hline \multicolumn{1}{c}{ Diagnosis } & $\begin{array}{c}\text { Number of } \\
\text { cases }\end{array}$ & $\begin{array}{c}\text { Percentage } \\
(\mathbf{\%})\end{array}$ \\
\hline Dyslipidaemia & 12 & 14.45 \\
Dyslipidaemia + hypertension & 38 & 45.78 \\
Dyslipidaemia + T2DM & 17 & 20.48 \\
Dyslipidaemia + hypertension + T2DM & 15 & 18.07 \\
Dyslipidaemia + CKD & 1 & 1.20 \\
\hline \multicolumn{1}{c}{ Total } & 83 & 99.98 \\
\hline
\end{tabular}

Legend: T2DM=type 2-Diabetes Mellitus, $\mathrm{CKD}=$ chronic kidney disease

TABLE 3. Cases of dyslipidaemia subjects who have had comorbid and treated with simvastatin

\begin{tabular}{|c|c|c|c|c|}
\hline $\begin{array}{c}\text { Medical } \\
\text { record No. }\end{array}$ & Sex & Age & Comorbid & $\begin{array}{c}\text { Type \& dosage of statin - Intensity } \\
\text { therapy }\end{array}$ \\
\hline 027810 & $\mathrm{~F}$ & 50 & T2DM, Hypertension & Simvastatin, $20 \mathrm{mg}$, MI \\
\hline 000166 & $\mathrm{~F}$ & 51 & T2DM, Hypertension & Simvastatin, $20 \mathrm{mg}$, MI \\
\hline 181971 & $\mathrm{~F}$ & 52 & T2DM, Hypertension & Simvastatin, $20 \mathrm{mg}$, MI \\
\hline 138527 & M & 51 & T2DM & Simvastatin, $20 \mathrm{mg}$, MI \\
\hline 029457 & $\mathrm{~F}$ & 53 & $\mathrm{~T} 2 \mathrm{DM}$ & Simvastatin, dose $\mathrm{n} / \mathrm{a}$ \\
\hline 006518 & $\mathrm{~F}$ & 67 & Hypertension & Simvastatin, dose $n / a$ \\
\hline
\end{tabular}

Legend: T2DM=Type2-Diabetes Mellitus, $\mathrm{MI}=$ moderate-intensity statin therapy

TABLE 3 shows cases of dyslipidaemia subjects who have had comorbid and treated with simvastatin.
TABLE 4 shows the percentage reduction of number of subjects who did not take routine check-up for their cholesterol level. It appears that measurements of total cholesterol, LDL, HDL and TG levels were not consistent.

TABLE 4. Percentage reduction in the number of subjects who re-examined cholesterol levels

\begin{tabular}{lccc}
\hline \multirow{2}{*}{ Cholesterol } & \multicolumn{2}{c}{ Number of subjects } & $\begin{array}{c}\text { \% of decrease of subjects who } \\
\text { did follows-up }\end{array}$ \\
\cline { 2 - 3 } & Pre-treatment & At the time of observation & 53 \\
TC & 83 & 39 & 89 \\
LDL-C & 27 & 3 & 92 \\
HDL-C & 25 & 2 & 82 \\
TG & 28 & 5 & 9 \\
\hline
\end{tabular}




\section{DISCUSSION}

Total Cholesterol, LDL-C, and TG levels were decreased, but only TC was significantly decreased. However, none of these results reached the target level, and responder rate was only $56 \%$. This inefficacy most likely caused by inappropriate of dosing, incompliant, and lack of laboratory monitoring. This was also in accordance to other studies conducted in three hospitals in Jakarta, Indonesia. ${ }^{13}$ However, other statins, such as atorvastatin, rosuvastatin, pravastatin and lovastatin were used in those three hospitals, and it was shown also that atorvastatin was more effective compared to other statins.

TABLE 2 shows that more than $85 \%$ subjects were diagnosed not only dyslipidaemia but also with other comorbid. The most comorbid observed were subjects with hypertension ( 38 subjects, $45.78 \%$ ), T2DM (17 subjects, 20.48\%), hypertension and T2DM (15 subjects, $18.07 \%$ ), and CKD (1 patient, $1.20 \%$ ), respectively. However, if we observed the dosage of the simvastatin, it was shown that all subjects received the same dosage, regardless of the cholesterol concentration they had and their comorbidities (TABLE 3). Adjustment of statin dose should be done regularly according to the cholesterol levels as well as existing comorbidities and in accordance to the newest guidelines. ${ }^{714,15}$ With regards to the issues on the relationship between statins and T2DM, we do not know whether there are new-onset of T2DM emerged among the subjects in our study. Some studies reported that all statins have the potency to increase the incident, but other studies mentioned that the evidence is not firm yet. ${ }^{16}$ Although, in JUPITER study, rosuvastatin $20 \mathrm{mg}$ versus placebo, has high hazard ratio (HR: 1.25, 95\% CI, 1.05-1.49) and in CORONA study (rosuvastatin $10 \mathrm{mg}$ versus placebo) with RR 1.13 (95\% CI, 0.86-1.50). Whereas, simvastatin, as it is most prescribed statin in this hospital, has lower RR. ${ }^{17}$ Other aspect that should be considered, what is the impact of statins on glycaemic control in subjects with DM? Due to insufficient methodological approaches and data, experts could not draw a firm conclusion on that issue. The available data suggest that, statin impacts on glycaemia control is very small (mean increase of $\approx 0.3 \%$ or less).

The use of statins in peripheral areas often could not follow the guidelines. Various factors underlie this issue. As it is shown in TABLE 3, most of the subjects did not take regular check-up for monitoring their therapy. Findings from previous research indicate that lack of medication adherence, follow-up examination of treatment outcomes by doctors, routine cholesterol checks and other clinical examinations are commonplace in health care facilities in developing countries.

Nevertheless, since 4 years, Indonesia has been running a system of national health services named Jaringan Kesehatan Nasional-Badan Penyelenggara Jaminan Sosial (National Health Network - Social Security Assurance Agency) that applies to the whole community. Prior to this program, the people should pay from their own pocket for any health services they received. This could be the reason why most of the subjects did not comply with the guidelines. Through this program, it is hoped that the above problems will no longer occur. Initial examination and follow-up examination can be performed regularly, so monitoring the success of therapy can be guaranteed. Therefore, a further study to compare of health service in pre- and JKN-BPJS era, with regards to metabolic diseases should be considered.

\section{CONCLUSION}

Utilization of statins in Ambon District Hospital, Maluku can decrease all cholesterol 
levels were decreased. However, the responder rate is only $56 \%$. Therefore, dosage adjustment and prerequisite cholesterol level during and post-treatment measurement should be made regularly.

\section{ACKNOWLEDGEMENTS}

The authors would like to thank the Medical Record Department of the Dr. Haulussy Hospital, Ambon for valuable assistance during the study.

\section{REFERENCES}

1. Jones PJH, Lamarche B, Kendall CWC, Faulkner D, Hoshizaki S, Leiter L, et al. Foods given at 2 levels of intensity of dietary advice on serum lipids in hyperlipidemia. Nutrition 2012; 306(8):831-9.

2. Group SSSS. Randomised trial of cholesterol lowering in 4444 patients with coronary heart disease: the Scandinavian Simvastatin Survival Study (4S). Lancet 1994; 344(8934):1383-9.

3. Pedersen TR, Olsson AG, F rgeman O, Kjekshus J, Wedel H, Berg K, et al. Lipoprotein changes and reduction in the incidence of major coronary heart disease events in the Scandinavian Simvastatin Survival Study (4S). Circulation. 1998; 97(15):1453-60. https://doi.org/10.1161/01.CIR.97.15.1453

4. Shepherd J, Cobbe SM, Ford I, Isles CG, Lorimer AR, Macfarlane PW, et al. Prevention of coronary heart disease with pravastatin in men with hypercholesterolemia. N Engl J Med 1995;333(20):1301-8.

ht tps://doi.org/10.1056/ NEJM199511163332001

5. West of Scotland Coronary Prevention Study Group. Influence of pravastatin and plasma lipids on clinical events in the West of Scotland Coronary Prevention Study
(WOSCOPS). Circulation 1998; 97:1440-5. https://doi.org/10.1161/01.CIR.97.15.1440

6. Kazi DS, Penko JM, Bibbins-Domingo K. Statins for primary prevention of cardiovascular disease. Med Clin North Am 2017; 101(4):689-99. https://doi.org/10.1016/j.mcna.2017.03.001

7. Gulati A, Sreenivas C, Talwalkar P, Baxi H. Journey in guidelines for lipid management: From adult treatment panel (ATP)-I to ATPIII and what to expect in ATP-IV. Indian J Endocrinol Metab 2013;17(4):628. https://doi.org/10.4103/2230-8210.113753

8. Stein EA. The power of statins : aggressive lipid lowering. Clin Cardiol 2003;26 (4 suppl 3): III25-31. https://doi.org/10.1002/clc.4960261506

9. Stone NJ, Robinson J, Lichtenstein AH, Merz CNB, Blum CB, Eckel RH, et al. 2013 AC/AHA guideline on the treatment of blood cholesterol to reduce atherosclerotic cardiovascular risk in adults: a report of the American College of Cardiology/American Heart Association Task Force on Practice Guidelines. Circulation 2013; 129(25 Suppl 2):S1-45.

10. García-Gil M, Blanch J, Comas-Cufí M, Daunis-I-Estadella J, Bolíbar B, Martí R, et al. Patterns of statin use and cholesterol goal attainment in a high-risk cardiovascular population: a retrospective study of primary care electronic medical records. J Clin Lipidol. 2016;10(1):134-42. https://doi.org/10.1016/j.jacl.2015.10.007

11. Primatesta P \& Poulter NR. Lipid concentrations and the use of lipid lowering drugs: evidence from a national cross sectional survey. BMJ 2000; 321:1322-5. https://doi.org/10.1136/bmj.321.7272.1322

12. Davidson MH. Differences between clinical trial efficacy and real-world effectiveness. Am J Manag Care 2006;12(15):405-11.

13. Simatupang A. Pattern of statin use in several Hospitals in Jakarta . A cross sectional study. 
Jurnal Kedokteran YARSI 2006; 14(3): 223 9.

14. Handelsman Y, Mechanick JI, Dagogojack S, Davidson J a. AACE Guidelines. Endocr Pract [Internet]. 2011;17(Volume 17, Supplement 2 / March-April 2011):1-35. Available from: http://aace.metapress.com/ content/t7g5335740165v13/fulltext.pdf

15. Miller PE \& Martin SS. Approach to statin use in 2016: an update. Curr Atheroscler Rep 2016;18(5): 20.

https://doi.org/10.1007/s11883-016-0578-1
16. Sattar N, Preiss D, Murray HM. Statins and risk of incident diabetes: a collaborative meta-analysis of randomised statin trials. Rev Port Cardiol 2010; 29(6):1077-8. https://doi.org/10.1016/S 0140 6736(09)61965-6

17. Colbert JD, Stone JA. Statin use and the risk of incident diabetes mellitus: a review of the literature. Can J Cardiol 2012; 28(5):581-9. https://doi.org/10.1016/j.cjca.2012.03.021 